\title{
Effect of IBA and NAA on Rooting and Growth of Mulberry Cuttings
}

\author{
Devana Pallavi ${ }^{*}$, G.L. Sharma ${ }^{1}$ and E.K. Naik ${ }^{2}$ \\ ${ }^{1}$ Department of Fruit Science, IGKV COA-492012, Raipur, Chhattisgarh, India \\ ${ }^{2}$ Department of Fruit Crops, HC \& RI-Periyakulam-625 604, TNAU, Tamil Nadu, India \\ *Corresponding author
}

\section{A B S T R A C T}

\begin{abstract}
Keywords
The experiment consists of six treatments of growth regulators and control i.e.

Mulberry cuttings,

Growth regulators

NAA 500 ppm, NAA 1000 ppm, NAA 1500 ppm, IBA 1000 ppm, IBA 1500 ppm and IBA $2000 \mathrm{ppm}$, were replicated four times in a complete randomized design

Article Info

Accepted:

04 October 2018

Available Online:

10 November 2018 (CRD). Presented data indicate that maximum number of shoots per cutting, maximum number of leaves per shoot, maximum number of roots per cutting, maximum length of roots $(\mathrm{cm})$ were recorded under IBA $2000 \mathrm{ppm}$ followed by IBA $1500 \mathrm{ppm}$, were significantly superior to the other growth regulators and control.
\end{abstract}

\section{Introduction}

Mulberry (Morus sp.) has been domesticated over thousands of years and has been adapted to a wide area of tropical, subtropical, and temperate zones of Asia, Europe, North and South America, and Africa. Most common types are White Mulberry (Morus alba L.), Black Mulberry (Morus nigra L.) and Red Mulberry (Morus rubra L.) and origins are Eastern and Central China, South West Asia and Central North America respectively. It belongs to family Moraceae and there are more than 100 species under the genus Morus. It is perennial, fast growing fruit tree and thrives well in all types of climate. The mulberry leaves and fruits are rich in protein and vitamins are long being exploited as animal feed or food products in several countries. Several studies have shown antioxidant, antiviral, anti-inflammatory hypolipidemic, anti-hyperglycemic, neuroprotective (Pan and Lou, 2008), antiHIV, antihypotensive and cytotoxic activities of different species of Morus (Du et al., 2003). The leaves of Morus alba bestowed with precious phytochemicals such as coumarins, flavonoids and phenols are found to be useful in reducing blood pressure and cholesterol level in human body (Sheng-qin and $\mathrm{Wu}$, 2003; Zhang et al., 2009). A wildly growing rustic mulberry plant, Morus nigra L. is reported to have medicinal values particularly in treating arthritis, diabetes and rheumatis (Perez- Gregorio et al., 2011). Two new flavonoids have also been isolated from the leaves of this plant species (Wang et al., 2009). Recently, the antioxidant potential of 
the extracts obtained from different mulberry plant parts viz., leaves, branches, roots and fruits was investigated by several researchers (Andallu et al., 2001). Among the 28 fruits commonly consumed in China, mulberry pulp was characterized by one of the highest values of the ferric reducing antioxidant power (FRAP) at $4.11 \mathrm{~m} . \mathrm{mol} / 100 \mathrm{~g}$ wet weight.

The fruits of mulberry are a multiple type of fruit, as all the flower of the inflorescence give rise to a single fruit. The fruit is green but changes to purplish through various shades of pink, red, brown, etc. due to certain chemical contained in the juice. It is also good for brain heart, spleen and helps curing diarrhea and intestinal ulcers. It is considered as a laxative and oral juice administration is found good drink during convalescence after a febrile illness. Mulberry fruit is well known as esteemed dessert fruit and having high source of vitamin $\mathrm{C}$ which is commonly used for the jams, jellies, cooling beverages and wines. Contains moisture [85 percent] proteins [0.7 percent], fats [0.4 percent], carbohydrates [12.2 percent], calcium [80mg], phosphorous [20 mg,] iron [2.6mg,] carotene [vitamin A, 60 IU], thiamin [58g], nicotinic acid [0.2 ug], riboflavin [2ug] and ascorbic acid [10ug] per $100 \mathrm{~g}$. Besides these, it also contains malic acid, citric acid, pectin, mucilage and coloring matter.

Mulberry is commercially propagated from cuttings because of distinct advantages like speedy multiplication of parent materials and maintenance of the desired characters of the mother plants. Therefore in order to improve rooting ability and success percent, the technique has been improved in which synthetic root promoting growth regulator are used. Indole- 3- Butyric Acid (IBA) is the best growth regulator for promoting rooting of a large number of species. Besides, application of NAA also has great potential in improving rooting of cutting in most of the species.

\section{Materials and Methods}

The Investigation was carried out at Horticulture Farm, Indira Gandhi Krishi Vishwavidyalaya, Raipur (C.G.) during the year 2017-2018 in kharif and rabi season. The experiment consists of six treatments of growth regulators and control i.e. NAA 500 ppm, NAA 1000 ppm, NAA 1500 ppm, IBA 1000 ppm, IBA 1500 ppm and IBA 2000 ppm were replicated four times in a complete randomized design (CRD). Ten hardwood cuttings of $15-20 \mathrm{~cm}$ in length were taken for each treatment in each replication. Two third parts of cuttings (two-third of $25 \mathrm{~cm}$.) was inserted in the media at a slight angle to the vertical.

\section{Results and Discussion}

The cuttings treated with IBA 2000 ppm recorded greater number of shoots per cutting than the cuttings treated with IBA 1500 ppm which could be attributed to enhancement of physiological functions in the cuttings favourably (Iqbal et al., 1999) at this concentration. Earliness in sprouting, increase in number of sprouts and sprout length might be due to better utilization of stored carbohydrates, nitrogen and other factors with the aid of growth regulators (Chandramouli, 2001). IBA at $2000 \mathrm{ppm}$ produced healthier, lengthy roots which help in absorption of water and nutrients that have great influence on production of more number of leaves by the cutting. The increase in number of leaves with IBA 2000 ppm might be due to more number of roots, plant height and branches per cutting (Ismail and Asghar, 2007).

The induction of maximum number of roots in the treated cutting may be due to the fact that cambial activity involved in root initiation is stimulated by growth regulators in many species as reported by (Digby and Wanerman, 1965) in pea. 


\begin{tabular}{|c|c|c|c|c|c|c|c|c|}
\hline \multirow[t]{2}{*}{ Observations } & \multicolumn{8}{|c|}{ Treatments } \\
\hline & Control & $\begin{array}{l}\text { NAA } \\
500 \text { ppm }\end{array}$ & $\begin{array}{l}\text { NAA } \\
1000 \\
\text { ppm }\end{array}$ & $\begin{array}{l}\text { NAA } \\
1500 \\
\text { ppm }\end{array}$ & $\begin{array}{l}\text { IBA } \\
1000 \\
\text { ppm }\end{array}$ & $\begin{array}{l}\text { IBA } \\
1500 \\
\text { ppm }\end{array}$ & $\begin{array}{l}\text { IBA } \\
2000 \\
\text { ppm }\end{array}$ & $\begin{array}{l}\mathrm{CD} \text { at } \\
5 \%\end{array}$ \\
\hline $\begin{array}{l}\text { No. of shoots per } \\
\text { cuttings at 90DAP } \\
\end{array}$ & 1.6 & 1.7 & 1.83 & 1.93 & 2.12 & 2.29 & 2.67 & 2.02 \\
\hline $\begin{array}{l}\text { No. of leaves per } \\
\text { shoot at } 90 \text { DAP } \\
\end{array}$ & 3.31 & 5.29 & 5.38 & 5.48 & 6.24 & 6.37 & 7.31 & 0.07 \\
\hline $\begin{array}{l}\text { No. of roots per } \\
\text { cutting }\end{array}$ & 5.7 & 7.67 & 8.82 & 11.5 & 12.45 & 14.95 & 20.97 & 0.98 \\
\hline Length of roots (cm) & 6.5 & 8.07 & 10.57 & 13.07 & 14.7 & 20.55 & 22.12 & 0.97 \\
\hline
\end{tabular}

The variation in dose response to the number of roots might be attributed to the varietal and climatic differences in the location. The reason for recording longest root may be attributed to the action of auxin activity which might have caused hydrolysis and translocation of carbohydrates and nitrogenous substances towards the base of cuttings and resulted in accelerated cell division and cell elongation under suitable environment. Another possible reason may be due to the early formation of roots and more utilization of reserved food materials of the treated cuttings (Ghatnatti, 1997).

\section{References}

Andallu, B., Suryakantham, V., Lakshmi Srikanthi, B. and Reddy, G.K. 2001. Effect of mulberry (Morus indica L.) therapyon plasma and erythrosite membrane lipids in patients with type 2 diabetes. Journal of Clinica Chimica Acta., 314 (1): 47-53.

Chandramouli, H. 2001. Influence of growth regulators on the rooting of different types of cuttings in Bursera penicilliata (DC) Engl. M.Sc. (Agri.) Thesis, University of Agricultural Sciences, Bangalore, p 51-53.

Digby, J. and Wannerman, E. 1965. A note on the effect of shoot and root apex secondary thickening in pea radicle. New Phytohormones, 46: 168-170.
Du, J., He, Z.D., Jiang, R.W., Ye, W.C. and $\mathrm{Xu}, \mathrm{H} . \mathrm{X}$. 2003. Antiviral flavonoids from the root bark of Morus alba L. Journal of Phytochemistry, 62 (34):1235-1238.

Ghatnatti, S.A. 1997. Stuides on propagation of Duranta plumeri Jacq. Var. Goldiana by stem cuttings with growth regulators under mist. M.Sc. (Agri.) Thesis, University of Agricultural Sciences. Dharwad, p 35-37.

Iqbal, M., Subhan, F., Ghafoor, A. and Jilani, M.S. 1999. Effect of different concentrations of IBA on root initiation and plant survival of apple cuttings. Pakistan Journal of Biological Sciences, 2(4): 1314-1316.

Ismail, S.M. and Asghar Hussain, I. 2007. Effect of indole butyric acid and types of cuttings on root initiation of Ficus Hawaii. Sarhad Journal of Agriculture, 23(4):919-925.

Pan, G. and Lou, C.F. 2008. Isolat ion of an 1-aminocyclopropane-1-carboxylate oxidase gene from mulberry (Morus alba L.) and analysis of the function of this gene in plant development and stresses response. Journal of Plant Physiology, 165 (1):1204-1213.

Perez-Gregorio, M.R., Regueiro, J., AlonsoGonzalez, E., Pastrana-Castro, L.M. and Simal-Gandara, J. 2011. Influence of alcoholic fermentation process on antioxidant activity and phenolic levels 
from mulberries (Morus nigra L.). LWT-Food Science and Technology, 44 (3): 1793-1801.

Sheng-qin, Z.O.U. and Wu, C.H.E.N. 2003. A review on chemical constituents, pharmacological activity and application of mulberry leaves. Journal of Chemical Industry of Forest Products, 1 (2): 1-8.
Wang, L., Gong, T. and Chen, R.Y. 2009. Two new prenyl flavonoids from Morus nigra L. Journal of Chinese Chemistry., 20 (4):1469-1471.

Zhang, M., Chen, M., Zhang, H.Q., Sun, S., Xia, B. and $\mathrm{Wu}$, F.H. 2009. In vivo hypoglycemic effects of phenolics from theroot bark of Morus alba. Journal of Fitoterapia, 80(2):475-477.

\section{How to cite this article:}

Devana Pallavi, G.L. Sharma and Naik, E.K. 2018. Effect of IBA and NAA on Rooting and Growth of Mulberry Cuttings. Int.J.Curr.Microbiol.App.Sci. 7(11): 305-308. doi: https://doi.org/10.20546/ijcmas.2018.711.037 